DOI: $10.4274 /$ tod. 13008

Turk J Osteoporos 2018;24:21-5

\title{
Is There an Effect of Patient's Age, Weight, Height and Body Mass Index on Positioning Errors During Scan Acquisition of Dual X-ray Absorptiometry?
}

\author{
Hastanın Yaşı, Ağırlığı, Boyu ve Vücut Kitle Indeksi Dual X-ray Tetkiki Esnasında Oluşan \\ Pozisyonlama Hatalarına Etkili Mi? \\ (D) Filiz Tuna, (D) Derya Demirbağ Kabayel* \\ Trakya University Faculty of Health Science, Department of Physical Therapy and Rehabilitation, Edirne, Turkey \\ *Trakya University Faculty of Medicine, Department of Physical Medicine and Rehabilitation, Edirne, Turkey
}

\section{Abstract}

Objective: Patient positioning during dual energy X-ray absorptiometry examination is important in assessing bone mineral density. While the role of the technician is considered important on correct positioning, the effect of the patient characteristics on positioning is not adequately explained. The aim of this study is investigate whether postmenopausal women's characteristics such as age, weight, height, and body mass index affect the positioning errors.

Materials and Methods: Dual energy X-ray absorptiometry reports and files of postmenopausal women were reviewed retrospectively. According to the values of body mass index three groups were formed; normal, overweight and obese. Forty one patients were included in each group. Only the images of the Hologic dual energy X-ray absorptiometry device were participated to assessment. Patients with positioning error were identified using the lumbar and hip region images in the dual energy X-ray absorptiometry output reports. The difference in positioning error rates between the body mass index groups was determined by Pearson's chi-square test. The effect of age, height, weight, and body mass index of patients on positioning errors was examined by simple linear regression analysis.

Results: Distribution of positioning errors between normal, overweight and obese groups were determined as 35.3\% (36), 29.4\% (30), and $35.3 \%$ (36), respectively. The distribution of correctly positioned patients in the same groups were; $23.8 \%(5), 52.4 \%(11)$, and $23.8 \%$ (5), respectively. No statistically significant difference was found between the groups in terms of positioning errors (Pearson's chi-square, $\mathrm{p}=0.127)$.

Conclusion: Patient characteristics such as age, height, weight, and body mass index do not affect positioning errors statistically significant level.

Keywords: Body mass index, densitometry, postmenopausal osteoporosis, positioning errors

\section{$\ddot{O z}$}

Amaç: Dual enerji X-ışııı absorbsiyometri tetkiki esnasında hastanın pozisyonlaması, kemik mineral yoğunluğu değerlendirmesinde önemlidir. Doğru pozisyonlama üzerine teknisyenin rolü önemli kabul edilirken, hastaya ait özelliklerin bu pozisyonlamaya etkisi yeterince açıklanmamaktadır. Bu araştırmadaki amacımız; postmenopozal kadınların yaş, boy, kilo ve vücut kitle indeksi gibi özelliklerinin pozisyonlama hatalarına etkileri olup olmadığını araştırmaktır

Gereç ve Yöntem: Post-menopozal kadınlara ait dual enerji X-ısını absorbsiyometri raporları ve dosyaları retrospektif olarak incelendi. Beden kitle indeksi değerlerine göre 3 grup oluşturuldu; normal, fazla kilolu ve obez. Her bir gruba 41 hasta dahil edildi. Yalnızca Hologic cihazına ait görüntüler değerlendirmeye katıldı. Dual enerji X-sşını absorbsiyometri çıktı raporlarındaki bel ve kalça bölgesi görüntüleri kullanılarak, pozisyonlama hatası olan hastalar tanımlandı. Vücut kitle indeksi grupları arasında pozisyonlama hata oranları arasındaki fark Pearson ki-kare testi ile belirlendi. Yaş, boy, ağırlık ve vücut kitle indeksinin pozisyonlama hataları üzerine etkisi basit doğrusal regresyon analizi ile incelendi. Bulgular: Normal, aşıı kilolu ve obez gruplar arasındaki pozisyonlama hataları dağılımı sırasıyla \%35,3 (36), \%29,4 (30) ve \%35,3 (36) saptandı. Aynı gruplarda doğru pozisyonlanmış hastaların dağılımı sırasıyla; \%23,8 (5), \%52,4 (11) ve \%23,8 (5) idi. Pozisyonlama hataları açısından gruplar arasında istatistiksel olarak anlamlı fark saptanmadı (Pearson ki-kare, $p=0,127$ ).

Sonuç: Yaş, boy, ağılık ve beden kütle indeksi gibi hastaya ait özellikler pozisyonlama hatalarını istatistiksel olarak anlamlı düzeyde etkilemez. Anahtar kelimeler: Vücut kitle indeksi, dansitometri, postmenopozal osteoporoz, pozisyonlama hataları

Address for Correspondence/Yazıșma Adresi: Filiz Tuna MD, Trakya University Faculty of Health Science, Department of Physical Therapy and Rehabilitation, Edirne, Turkey Phone: +90 5057912727 E-mail: drftuna@gmail.com ORCID ID: orcid.org/0000-0002-9563-8028 Received/Geliş Tarihi: 19.02.2018 Accepted/Kabul Tarihi: 25.06.2018

This study was presented as Oral Presentation at Turkish Rheumatology Congress with International Participants in 2017 (Antalya, $22-26$ March 2017 ). 


\section{Introduction}

Dual energy X-ray absorptiometry (DEXA) is often used to assess bone mineral density (BMD) (1).

Acquisition is a term that refers to the patient's positioning on the DEXA desk and the scan process (2). At this stage, the values obtained (e.g., BMD, body fat percentage) may be affected by the patient's positioning and evaluation (3).

In daily practice, patient positioning errors are detected at various rates ranging from $12 \%$ to $91 \%$ (4-7). The position of the patient is checked during the scan from the computer monitor or from the report output. In these images; the lumbar spine should be straight and have equal soft tissue on both sides. Spinous processes should be observed in the midline. At the top of the image, the lower part of the T12 vertebra and the ribs, and at the lower part of the image the $L 5$ and each of the two iliac crests (sacrum and part of the pelvis) should be visible. In the position for the hip region; the femur shafts should be parallel to the edge of the image. Little trochanter should not appear at all. This is an indication of the optimal internal rotation of the hip at $15^{\circ}(3)$. Total body DEXA used for body composition detection also focuses on patient positioning (5). Although there are regular trainings for health professionals in order to reduce the error rates (8), there are few studies that examine the factors that can affect the errors $(3,9)$.

In postmenopausal women, the increase in body mass index (BMI) is known to affect BMD positively (10). This positive effect is attributed to the mechanical loading of the bones. On the other hand, factors such as advancing age and obesity have an adverse effect on the person's balance (11). The decline of cognitive functions in the aging process is also considered to be part of the physiological process. Therefore, it is possible that the patient positioning by the technician during the acquisition may be affected by the patient-induced reason. For this reason, we investigated the positioning errors of postmenopausal patients in different BMI groups in our study and aimed to investigate the difference between the error rates in these groups. In addition, we aimed to investigate the effects of age, weight, height and BMI factors on positioning errors in postmenopausal women.

\section{Materials and Methods}

Our retrospective, cross-sectional study was carried out with the approval of the local Ethics Committee (TÜTF-BAEK 2017/147). DEXA reports and files of postmenopausal women were reviewed retrospectively. Only the images of the Hologic DEXA were used. Exclusion criteria were; The reports obtained from devices other than the Hologic DEXA of our university, images printed in poor quality, the files that are not fully completed, and data of male, premenopausal women and children. BMls of patients were calculated taking into account the weight and height values in the records of all postmenopausal female patients enrolled in physical medicine and rehabilitation osteoporosis polyclinic between January 2014 and July 2015. Considering the BMI classification of the World Health Organization, patient data were divided into three groups. BMI results were grouped as normal, overweight and obese, with 18.5-24.9, 25.0-25.9 and 30.0 or higher, respectively. A maximum of 41 patients were identified for the normal group. For this reason, with the aim of creating an equal number of patients in the other 2 groups; 41 of the patients were randomly selected from the files in overweight and obese groups. Thus, a total of 123 DEXA reports of postmenopausal women were included in the study. Using the visuals (lumbar and hip area) on the DEXA reports, outputs with positional error was identified.

When positioning errors were determined, the International Society for Clinical Densitometry official positions for 2015 were taken into account (8). With a checklist we created in our previous study, positional errors were identified for the lumbar and hip regions $(7-9,12)$. The effect of age, height, weight and $\mathrm{BMI}$ on positioning errors was examined.

\section{Statistical Analysis}

The frequency of positioning errors was determined using descriptive statistics. The descriptive statistics used were number and percentage for categorical data and median (minimummaximum) and quantitative mean \pm standard deviation for quantitative data. The effects of age, height, weight and BMI on positioning errors were examined by simple linear regression analysis. The difference in error rates between the groups was determined by Pearson chi-square test. Statistical evaluations were performed in SPSS 20.0 (License no: 10240642) program. Values of $p<0.05$ were considered statistically significant.

\section{Results}

DEXA reports of 123 postmenopausal women were divided into three groups according to the BMI of the patients. The mean age, height, weight and BMI of normal, overweight and obese groups were determined. The groups were homogeneous in terms of age and height $(p=0.263)$ (Table 1$)$.

Positioning errors were detected in 102 patients. The mean age of the patients with and without errors were $60.00 \pm 9.51$ and $59.74 \pm 9.20$ years, respectively $(t=0.119, p=0.905)$.

When the DEXA measurements that were found to be faulty were examined by BMI groups; 35.3\% (36) were normal, $29.4 \%$ (30) were overweight and $35.3 \%$ were in the obese group (Table 2).

The distribution of 21 correctly positioned patients according to the groups were; $23.8 \%$ (5) were normal, $52.4 \%$ (11) were overweight and $23.8 \%$ (5) were obese. There was no significant difference between the BMI groups in terms of positioning errors $\left(\chi^{2}=4.134, p=0.127\right)$.

Age, height, weight and $\mathrm{BMl}$; it was found that positioning errors (lumber, hips and both regions) were not significantly affected in all patients and separately in each group (Table 3). 


\section{Discussion}

BMD is taken into account in the treatment of osteoporosis patients. DEXA is still the gold standard in the detection of BMD (13). This indisputable value of DEXA depends on the suitability of many stages. The selection and calibration of devices used in this fit, the knowledge of technicians (acquisition), and the knowledge and skill of the clinicians who make the diagnosis and treatment decision $(2,3,14)$.

Messina et al. (6), explored the types and prevalence of errors that occurred during DEXA evaluation and founded error rates as; data analysis, 79\%; patient positioning, 12\%; presence of artefacts, 7\%; and demographic data, \%2. In our previous study, we retrospectively reviewed the DEXA acquisition phase. We checked 323 DEXA output and found that patient positioning errors were $64.7 \%$ and $60.7 \%$ in the spine and hip region, respectively. We determined the correct positioning ratio of both regions as low as $16.1 \%$.

In the same study, we also assessed the validity of the analysis phase, which is an important element in the continuation of the gold standard, in particular the role of the clinician. The spinal DEXA image ratio required to recalculate BMD and T-score was found to be $34.7 \%$. A statistically significant difference was found between the first report results and the second results of the clinician's evaluation, between T-scores and BMD results (7). In our previous work, or in other studies in the literature, the fact that positioning mistakes are high is necessary to evaluate the possible factors that will affect this error. Although DEXA was the primary responsibility of the technician, it was interesting to see whether the patient's characteristics were influencing positioning errors. Due to the absence of publications investigating this issue in the literature; some questions aroused curiosity. If the patient is obese or has normal BMI, can it cause difficulty in positioning? Possible perception problems that can occur with increasing age can lead to errors in positioning the patient? This work is basically designed to search for answers to these questions.

Since we could not identify a similar methodology of the study we conducted within our research, we discussed the focus on the positioning errors in the DEXA acquisition phase. To our

\section{Table 1. Descriptive of groups}

\begin{tabular}{|c|c|c|c|c|c|c|c|c|c|}
\hline & & \multirow[b]{2}{*}{$\mathbf{N}$} & \multirow[b]{2}{*}{ Mean (SD) } & \multirow[b]{2}{*}{ SE } & \multicolumn{2}{|c|}{$95 \% \mathrm{Cl}$} & \multirow[b]{2}{*}{ Min } & \multirow[b]{2}{*}{ Max } & \multirow[b]{2}{*}{$\mathbf{p}$} \\
\hline & & & & & Upper & Lower & & & \\
\hline \multirow[t]{4}{*}{ Age } & Normal & 41 & $58.0(8.5)$ & 1.3 & 55.4 & 60.7 & 47 & 77 & \multirow{4}{*}{0.888} \\
\hline & Overweight & 41 & $60.0(9.8)$ & 1.5 & 56.9 & 63.1 & 41 & 84 & \\
\hline & Obese & 41 & $61.3(9.3)$ & 1.5 & 58.4 & 64.3 & 44 & 81 & \\
\hline & Total & 123 & $59.8(9.2)$ & 0.8 & 58.1 & 61.4 & 41 & 84 & \\
\hline \multirow[t]{4}{*}{ Height } & Normal & 41 & $155.6(5.1)$ & 0.8 & 154.0 & 157.2 & 143 & 165 & \multirow{4}{*}{0.910} \\
\hline & Overweight & 41 & $154.4(4.7)$ & 0.7 & 152.9 & 155.9 & 144 & 164 & \\
\hline & Obese & 41 & $154.1(4.8)$ & 0.8 & 152.6 & 155.6 & 142 & 168 & \\
\hline & Total & 123 & $154.7(4.9)$ & 0.4 & 153.8 & 155.6 & 142 & 168 & \\
\hline \multirow[t]{4}{*}{ Weight } & Normal & 41 & $56.4(5.3)$ & 0.8 & 54.7 & 58.1 & 43 & 68 & \multirow{4}{*}{0.000} \\
\hline & Overweight & 41 & $65.1(4.7)$ & 0.7 & 63.6 & 66.6 & 57 & 73 & \\
\hline & Obese & 41 & $83.1(12.1)$ & 1.9 & 79.2 & 86.8 & 64 & 113 & \\
\hline & Total & 123 & $68.2(13.7)$ & 1.3 & 65.7 & 70.6 & 43 & 113 & \\
\hline \multirow[t]{4}{*}{ BMI } & Normal & 41 & $23.3(1.4)$ & 0.2 & 22.8 & 23.7 & 19.4 & 25.0 & \multirow{4}{*}{0.000} \\
\hline & Overweight & 41 & $27.3(1.4)$ & 0.2 & 26.9 & 27.8 & 25.1 & 29.9 & \\
\hline & Obese & 41 & $35.0(5.0)$ & 0.8 & 33.4 & 36.5 & 30.0 & 50.2 & \\
\hline & Total & 123 & $28.5(5.8)$ & 0.5 & 27.5 & 29.5 & 19.4 & 50.2 & \\
\hline
\end{tabular}

Table 2. Distribution of poor positioning into the groups

\begin{tabular}{|c|c|c|c|c|c|c|c|}
\hline & \multicolumn{3}{|c|}{$\begin{array}{c}\text { Groups } \\
\text { N, \% }\end{array}$} & \multirow{2}{*}{$\begin{array}{l}\text { Total } \\
\mathrm{N}, \%\end{array}$} & \multirow[b]{2}{*}{$\chi^{2}$} & \multirow[b]{2}{*}{$\mathbf{p}$} \\
\hline & & Normal & Overweight & Obese & & & \\
\hline \multirow[t]{2}{*}{ Positioning } & Poor & $36,35.3$ & $30,29.4$ & $36,35.3$ & $102,100.0$ & 4.134 & 0.127 \\
\hline & Correct & $5,23.8$ & $11,52.4$ & $5,23.8$ & $21,100.0$ & - & - \\
\hline \multicolumn{2}{|l|}{ Total } & $41,33.3$ & $41,33.3$ & $41,33.3$ & $123,100.0$ & - & - \\
\hline
\end{tabular}


knowledge, no data are available on the effect of the patient's demographics on positioning errors.

Patient positioning during DEXA examination is known to affect $B M D$ results $(3,13,14)$. However, some studies on patient positioning are concentrated in the field of DEXA total body composition with regional analysis $(15,16)$.

The data in this area indicates that patient positioning is particularly important when analyzing regional body composition compared to whole body measurement (5). In the ISDC recommendations, positioning information is also listed under the DEXA acquisition heading of body composition measurements, and the acquisition is defined as "The process of positioning and scanning the patient on the DEXA table" (2). For the use of the central DEXA, only information about the selection of the spine and hip region of interest is obtained (8). Despite the fact that the error rates are high in the current data, they are not sufficiently addressed. However, it is stated in the ISDC's final report that positioning may affect the results (2). In a study using the human cadastral model, it is reported that positioning the spine affects BMD values. In this study, as the lordosis and kyphosis of the cadaver increased, the BMD values decreased by $17.5 \%$ and $11.5 \%$, respectively (14). The effect of leg positioning on BMD is addressed in a study included 1039 patients. Ikegami et al. (15), compare the simple supine position (supine position) with the standard position (supine position with supported hip and knee flexion at $90^{\circ}$ ) and no statistical difference were reported.

When the effect of BMI on the smallest detectable differences (SDDs) is examined; the SDS values determined in terms of bone mass evaluation of obese and non-obese children were found to be similar. SDDs are necessary to show that the resulting change is not a result of a measurement error. Especially the detection of SDSs has been found to be important for DEXA reproducibility (17). In contrast, a different study investigating the effects of BMI and fat ratio on delicate faults indicated that obese cases require special attention during work. Wosje et al. (18), achieved this result by total and regional body DEXA measurements of BMD, fat and lean tissue in normal, overweight and obese participants. Lewiecki and Lane (3), who pointed out the DEXA acquisition phase inaccuracy (3), have indicated that patient size should be taken into account when determining the scan mode duration. In our study, no statistically significant difference was found between BMI groups in terms of positioning errors.

\section{Study Limitations}

The limitation of our study can be considered to be that the effects of cognitive status and educational levels of patients on positioning errors were not examined.

\begin{tabular}{|c|c|c|c|c|c|}
\hline Independent variable & Constant & $\begin{array}{l}\text { Regression } \\
\text { coefficient (B) }\end{array}$ & $R^{2}$ & $t$ & $p$ \\
\hline \multicolumn{6}{|l|}{ Age } \\
\hline Total & 0.114 & 0.000 & 0.000 & 0.119 & 0.905 \\
\hline Normal & 58.667 & -5.267 & 0.043 & -1.318 & 0.195 \\
\hline Overweight & 0.013 & 0.04 & 0.009 & 0.582 & 0.564 \\
\hline Obese & -0.060 & 0.003 & 0.007 & 0.523 & 0.604 \\
\hline \multicolumn{6}{|l|}{ Height } \\
\hline Total & 0.893 & -0.005 & 0.040 & -0.663 & 0.508 \\
\hline Normal & 155.583 & 0.017 & 0.000 & 0.007 & 0.995 \\
\hline Overweight & 1.193 & -0.006 & 0.004 & -0.393 & 0.697 \\
\hline Obese & 1.191 & -0.007 & 0.010 & -0.635 & 0.529 \\
\hline \multicolumn{6}{|l|}{ Weight } \\
\hline Total & 0.303 & -0.002 & 0.005 & -0.778 & 0.438 \\
\hline Normal & 56.194 & 1.606 & 0.010 & 0.636 & 0.528 \\
\hline Overweight & 0.641 & -0.006 & 0.040 & -0.376 & 0.709 \\
\hline Obese & 0.524 & -0.005 & 0.031 & -1.117 & 0.271 \\
\hline \multicolumn{6}{|l|}{ BMI } \\
\hline Total & 0.270 & -0.003 & 0.003 & -0.587 & 0.558 \\
\hline Normal & 23.188 & 0.597 & 0.020 & 0.901 & 0.373 \\
\hline Overweight & 0.353 & -0.003 & 0.000 & -0.062 & 0.951 \\
\hline Obese & 0.450 & -0.009 & 0.020 & -0.887 & 0.381 \\
\hline
\end{tabular}




\section{Conclusion}

As a result of our study, we found that the demographic and anthropometric characteristics of the patient such as age, height, weight, and BMI were ineffective on positioning errors. Our results support the view of Lewiecki and Lane (3): "Correct positioning primarily depends on the skill of the technologist". Therefore, the technician's role in reducing error rates is great.

\section{Ethics}

Ethics Committee Approval: The Local Ethics Committee of Trakya University Faculty of Medicine approved the study (no: TÜTF-BAEK 2017/147).

Informed Consent: No additional patient confirmation was obtained because the planned study was retrospective and the patient file data were used anonymously.

Peer-review: Externally and internally peer-reviewed.

\section{Authorship Contributions}

Surgical and Medical Practices: F.T., D.D.K., Concept: F.T., D.D.K., Design: F.T., D.D.K., Data Collection or Processing: F.T., Analysis or Interpretation: F.T, D.D.K., Literature Search: F.T., Writing: F.T.

Conflict of Interest: No conflict of interest was declared by the authors.

Financial Disclosure: The authors declared that this study received no financial support

\section{References}

1. Cosman F, de Beur SJ, LeBoff MS, Lewiecki EM, Tanner B, Randall S, et al. Clinician's Guide to Prevention and Treatment of Osteoporosis. Osteoporos Int 2014;25:2359-81.

2. Lewiecki EM, Binkley N, Morgan SL, Shuhart CR, Camargos BM, Carey JJ, et al. Best Practices for Dual-Energy X-ray Absorptiometry Measurement and Reporting: International Society for Clinical Densitometry Guidance. I Clin Densitom 2016;19:127-40.

3. Lewiecki EM, Lane NE. Common mistakes in the clinical use of bone mineral density testing. Nat Clin Pract Rheumatol 2008;4:667-74.
4. Cetin A, Özgüçlü E, Özçakar L, Akinci A. Evaluation of the patient positioning during DXA measurements in daily clinical practice. Clinical Rheumatol 2008;27:713-5.

5. Libber J, Binkley N, Krueger D. Clinical observations in total body DXA: technical aspects of positioning and analysis. I Clin Densitom 2012;15:282-9.

6. Messina C, Bandirali M, Sconfienza LM, D'Alonzo NK, Di Leo G, Papini GD, et al. Prevalence and type of errors in dual-energy X-ray absorptiometry. Eur Radiol 2015;25:1504-11.

7. Tuna F, Yavuz S, Demirbağ Kabayel D, Sarıkaya A. Effects of clinical reanalysis in dual-energy X-ray absorptiometry reports. Turk J Phys Med Rehab 2017;63:201-6.

8. International Society for Clinical Densitometry. ISCD 2015 Official Positions Brochure. [Available from: https://iscd.app.box.com/v/ op-iscd-2015-adult. Accessed February 18, 2018.

9. Watts NB. Fundamentals and pitfalls of bone densitometry using dual-energy X-ray absorptiometry (DXA). Osteoporo Int 2004;15:847-54.

10. Wu SF, Du XJ. Body Mass Index May Positively Correlate with Bone Mineral Density of Lumbar Vertebra and Femoral Neck in Postmenopausal Females. Med Sci Monit 2016;22:145-51.

11. van Schooten KS, Pijnappels M, Rispens SM, Elders PJ, Lips P, van Dieën JH. Ambulatory fall-risk assessment: amount and quality of daily-life gait predict falls in older adults. J Gerontol A Biol Sci Med 2015;70:608-15.

12. Schousboe JT, Shepherd JA, Bilezikian JP, Baim S. Executive summary of the 2013 international society for clinical densitometry position development conference on bone densitometry. J Clin Densitom 2013;16:455-66.

13. Frimeth J, Galiano E, Webster D. Some physical and clinical factors influencing the measurement of precision error, least significant change, and bone mineral density in dual-energy $x$-ray absorptiometry. J Clin Densitom 2010;13:29-35.

14. Izadyar S, Golbarg S, Takavar A, Zakariaee SS. The Effect of the Lumbar Vertebral Malpositioning on Bone Mineral Density Measurements of the Lumbar Spine by Dual-Energy X-Ray Absorptiometry. J Clin Densitom 2016;19:277-81.

15. Ikegami S, Kamimura M, Uchiyama S, Nakamura Y, Mukaiyama $\mathrm{K}, \mathrm{Kato} \mathrm{H}$. Clinical Implications of Hip Flexion in the Measurement of Spinal Bone Mineral Density. J Clin Densitom 2016;19:270-6.

16. Knapp KM, Welsman JR, Hopkins SJ, Shallcross A, Fogelman I, Blake GM. Obesity Increases Precision Errors in Total Body DualEnergy X-Ray Absorptiometry Measurements. J Clin Densitom 2015;18:209-16.

17. Xu W, Chafi H, Guo B, Heymsfield SB, Murray KB, Zheng J, et al. Quantitative Comparison of 2 Dual-Energy $X$-ray Absorptiometry Systems in Assessing Body Composition and Bone Mineral Measurements. J Clin Densitom 2016;19:298-304.

18. Wosje KS, Knipstein BL, Kalkwarf HJ. Measurement error of DXA: interpretation of fat and lean mass changes in obese and nonobese children. J Clin Densitom 2006;9:335-40. 